\title{
J-SHMIC \\ UNDERSTANDING FORMATIVE AND SUMMATIVE ASSESSMENT FOR EFL TEACHERS: THEORETICAL REFLECTIONS ON ASSESSMENT FOR LEARNING
}

\author{
M. Ridhwan \\ STAI Auliaurrasyidin Tembilahan \\ email: aufadzakwan@msn.com
}

\begin{abstract}
The literatures showed that the important of assessment has brought so significance works and studies. Currently, the teacher's conception and belief to conduct assessment being questioned because of its nature, the cheating habit among students while assessing summative kind of test becomes the roots of all the problems occurred during the classroom test. They, especially EFL teachers should not determine by the test as the only gear to measure learning outcomes, using formative as assessment for learning is better proposed and understood rather than spotlighting the assessment of learning. Dispute summative can someway use feedback for formative purpose, it seems the roles of the teachers would take so little function for students' improvement. It is then suggested for EFL teachers, they should immense formative procedures over summative to enhance the learning target which has been previously shared with students. Eventually, if it is successfully offered and applied massively by teachers, the earlier problems found such as cheating, lower students' grade, would be diminished, and positively change the learning behavior. In addition, will not possible to transform teachers' conception and practice from being an "assessment of learning" into assessment for learning". The formative teachers will always examine their students based on the dynamic situation of their students, they viewed every dynamic problem found during classroom teaching and learning could be as feedback for teaching improvement and re-designed their teaching method in the classroom.
\end{abstract}

Keywords: Assessment, Formative, Summative

\section{MEMAHAMI PENILAIAN FORMATIVE DAN SUMMATIVE BAGI GURU BAHASA INGGERIS: REFLEKSI TEORI TERHADAP PENILAIAN UNTUK PEMBELAJARAN}

\begin{abstract}
Abstrak
Literatur menunjukkan bahwa pentingnya penilaian telah melahirkan banyak penelitian dan tulisan penting untuk dikaji, Saat ini, konsep penilaian yang diyakini oleh guru dipertanyakan karena keaslian dari penilaian tersebut telah berubah menjadi hanya sekedar pelaksanaan test untuk mengukur kemampuan
\end{abstract}


siswa. Selain itu, dikarenakan adanya budaya mencontek antara siswa merupakan akar permasalahan yang mengakibatkan test dari guru ternoda keasliaannya. Seyogyanya guru Bahasa Inggris tidak hanya terikat dengan test sumative sebagai satu-satunya alat untuk mengukur keberhasilan pembelajaran, tapi sebaiknya mereka membudayakan formative sebagai prosedur yang dilaksanakan dan dipahami. Sekalipun guru bisa menggunakan hasil test summative untuk keperluan formative, akan tetapi peranan guru dalam hal tersebut sangat minim, dikarenakan tidak semua hasil test bisa diperoleh guru untuk mendapatkan feedback dari siswanya. Oleh karena itu, disarankan bagi guru Bahasa Inggris untuk lebih memberdayakan penilaian formative dari pada test summative untuk memperoleh feedback dari siswa berdasarkan tujuan pembelajaran yang telah diketahui bersama. Akhirnya, apabila pelaksanaan formative ini bisa dijalankan dengan baik oleh guru, permasalahan awal seperti mencontek, rendahnya nilai akhir siswa akan dapat diminimalisir, bahkan secara positif bisa merubah pemahaman guru yang mulanya menjadikan test hanya sebagai alat ukur, menjadi guru yang bisa menggunakan test sebagai penilaian untuk meningkatkan pembelajaran. Guru yang formative akan selalu menilai siswanya berdasarkan perubahan situasi pembelajaran, mereka memandang setiap perubahan yang ditemui dikelas bisa dijadikan sumber feedback untuk meningkatkan pengajaran dan kemudian bisa meciptakan model pengajaran yang sesuai bagi kelasnya.

Kata Kunci: Penilaian, formative, sumative

\section{INTRODUCTION}

Assessing learner's performance is part of teacher's daily routine when teaching and learning administered during school days. At times, teacher uses formative (classroom observation) or greater uses learner's course experience result (summative) to measure his or her accomplishment of teaching (Wei Wei, 2015). All information obtained during and after the course is essential for teacher in creating more effective evaluation techniques (Meyer, 2009). After all, the practicality of evaluation cycling under terms of assessment, and test. Teacher's conception in those parts, is as the need to avoid misunderstanding or misinterpreting those concepts.

J-SHMIC, Vol 4, No 1, February 2017
In educational practice, both concept of assessment and test can become a synonymously applied for measuring student's achievement in certain course or subject. Yet defining them appropriately, assessment and test, however, setting up differently for purpose and its usage (Hughes, 1989). For novice teacher, both turn into misunderstanding, overlapping, and doubting within classroom practice.

Defining them theoretically, assessment is an ongoing process that encompasses wider range of methodological techniques (Brown \& Abeywickrama, 2010, p. 3). Further Sardareh and Saad (2013) pinpoint that "it is about assessing learners' progress, providing them with 
feedback and deciding on the next step the teaching and learning process" (p.2493). Whenever teacher gives appraisal toward student's responses defining as assessment contextually. A good teacher as argued by Brown and Abeywickrama (2010) will never cease to do an assessment whenever he or she teaches.

On the other hand, a test itself is a subset of assessment, a part of it which is hierarchy shepherded at the end of the course quantitatively, it is rather expressing an instrument to measure peak performance of learners (Marshall, 2011).

Therefore, test sometime sounds conflicting and creating a scariness which many learners being provoked whenever they hear its chorus; moreover, for those learners who were measured for their passing grade to any level of subject test or semester test. Test, so far, is prepared administratively, procedurally, as well as pre-determined by subsequent times given at the end of the completed course done by teachers (Brown, 2004). For here, as assessment would be the focus of this paper, the writer simply narrowing the discussion to assessment and giving little interest of specifics 'test' during the next sub discussion. Nevertheless, the term of test, later, perhaps being specifically defined as "summative" kind of assessment.

Currently, the teacher's conception and belief to conduct assessment being questioned because of its nature, the cheating habit among students while assessing summative kind of test becomes the roots of all the problems occurred during the

J-SHMIC, Vol 4, No 1, February 2017 classroom test. It is easier to find learners who conditionally prepared theirs notes before the test given. We cannot say that the teachers or examiners during the test could not arrange or surveil the habit of learners, but the learners and all of their cheating capabilities always escape or even successful to cheat among others. Have a look in national context, when national examination administered to schools, the teachers together with the teams, yet constantly controlling the answered in order the learners passed their examination. These writer's judgment can be easily observed from the primary level of education to secondary.

Hypothetically, the teachers are responsible to understand the advantages of the administered test given. Postulating on the above issues, teachers and learners are so determined by the test as the only gear to measure learning outcomes, meanwhile as previously pounded by assessment theory, there are at least formative assessment to dispense by teachers instead of focusing final test - summative - as the single procedure to appraise learner's performances Teachers conceptions on this is very important, moreover as illustrated by Gulikers, et.al. (2013) that teachers being trapped to see assessment as "assessment of learning" "not assessment for learning” (p.117).

Formative and summative assessment are some particular techniques of so many surviving evaluation theories. In fact, their existence as theory cannot be utilized functionally and practically until teachers change their conception. They, however, should realize its 
function and its applicability. So yet to be frankly, before discussing too far, the reaction of this paper's writing coming from the ideas of where assessment can be either formative or summative.

This issue is commonly appeared in the language area, the writer judges, if may not being exaggerated to say, that these kind of assessments and understanding of it, would be helpful especially for EFL teachers, or even for educators who have different fields of teaching disciplines. Some set procedures distinguishing between formative and summative would be examined later in discussion session; on how it is employed, characterized, and benefited for teachers. Upon classroom assessment practice, addressing this issue in education; especially in instructional design, is one of essential elements for teachers working as classroom evaluators (Scriven, 1991, as cited in Wholey, 1996).

\section{METHOD}

This study was a library study where the writer collected some literatures about formative and summative assessment, then the writer gave his own opinion regarding the issues, and proposed solution for EFL teachers as they are the focus on this study.

\section{DISCUSSION}

The literatures showed that the important of assessment has brought so significance works and studies. Thus, some authors on their studies may interested in assessment at higher education; where other fascinated at lower education. However, as writer declaimed -at least by contemporary literatures- that all the work of assessments derived since Black and William (1996, 1998a, 1998b), Sadler (1998); William (2000), and Black (2003c) successfully elaborated 'assessment' as important work involves in evaluation; which wellknown developed as the concept "assessment for learning" (Taras, 2005; Taras, 2009). Nevertheless, following its historical development, Scriven (1967) was the one who firstly introduced the concept of formative and summative assessment, which then permeated in the field of education, and spread out into health and social action programs (Misanchuk, 1978). At the present time, the literatures would not far beyond those names. These concepts, yet, attracting so many educators, even government to understand which ways to engage for developing the best evaluation programs.

\section{a. A distinction between summative and formative assessment}

Returning back to our definition on assessment, it is "the process of gathering the data about teachers teaching and their students' learning" (Hanna \& Dettmer, 2004 as cited in NIU, n.d p. 1). It refers to "a judgement which can be justified according to specific weighted set goals, yielding either comparative or numerical ratings" (Taras, 2005, p. 467) Similarly, as stated by Mousavi (2009) assessment is "appraising or estimating the level of magnitude of some attribute of a person" (Mousavi, 
2009, p. 36, as cited in Brown \& Abeywickrama, 2010, p. 3).

Those above definitions emphasize the word "collecting the data" of student's classroom performance about certain subject, any process resulting the data on how student reacting, giving feedback to his learning could be affirmed as assessment. However, this general terminology then divided again into what we have previously spelled as summative and formative assessment. If assessment refers as general procedure to measure performances, but those next two, are the detail processes of where and when should we use our assessment to gain effective learning purposes.

Summative assessment refers when teachers summarize students' learning near the end of a teaching cycle, then, they may use, not have to, giving that information for feedback (formative assessment) to improve teaching and learning (Lam, 2013). From this description, we can figure out that theoretically, summative would be conducted at the end of the course without addressing the feedback for students, while formative occurred primarily during the teaching and learning itself and teachers rationalize their evaluation sheet for solving the problem that students might have and use that information to improve next learning stages. It is considered formative, if only summative results be used for feedback purposes (Taras, 2005).

At this point of view, both summative and formative exactly attaching each other as performance appraisal concepts that measured students' performance about certain goals. Brookhart (2001) supported the ideas "all classroom assessment can be formative, but only if students use the information for formative purposes" (p. 154). A good analogy presenting both concepts like "the road test that is required to receive a driver's license" (Garrison \& Ehringhaus, 2007, p. 2), the evaluation stages during the road examination called formative, which is then used summatively to measure whether or not we have the driving skills necessary for a driver's license.

Clarified by Brown and Abeywickrama (2010), they used "forming" to enlighten the formative assessment, which indicates that evaluating students in the process of their skills with the goal of helping them. They further noted that in the formative process the teachers become the key to deliver to students in order they can internalize it for future learning progress. A simple process by teachers to deliver that feedback can be, for examples: "well done" comments when students delivered a right answer on questioning, or calling attention when students make some errors or mistakes.

An intense description on summative also by Brown, further highlighted that summative will often, but not always involves for decision making by institution.

$\mathrm{He}$ noted final exams in a course as one of the many examples of summative. Likewise, to measure and summarize what students have learned, and how well that students accomplished the learning objectives defined as summative assessment (Brown, 2004). 
As for here, we, then draw specifically what exactly characterized between formative and summative assessment. Although they both are appeared to be aligned each other, but the distinction between them are very clear. For sure, if formative has to be carried out by teachers (Harlen \& James, 1997), unlike formative, summative could also be done with teachers-free judgment because of its procedures taken by another, such as government national examiners. Table 1 will provide the clear distinction between the two in practice.

Table 1. The differences between formative and summative assessment in practice

\begin{tabular}{|c|c|c|}
\hline & Formative & Summative \\
\hline Nature & Classroom observation & Student course experience survey \\
\hline Assessor & Students, teachers & $\begin{array}{l}\text { Committees, examiners, } \\
\text { government }\end{array}$ \\
\hline Stakes & Relatively low & High stakes \\
\hline Purpose & $\begin{array}{l}\text { Identify problems and } \\
\text { weaknesses, provide feedback }\end{array}$ & $\begin{array}{l}\text { Evaluate students' performance } \\
\text { with numerical data }\end{array}$ \\
\hline Frequency & During teaching & $\begin{array}{l}\text { Once in a semester, or semester } \\
\text { year }\end{array}$ \\
\hline Participant & $\begin{array}{l}\text { Students, especially who have } \\
\text { lower performance in the class }\end{array}$ & All students \\
\hline
\end{tabular}

Wei Wei, (2015. p. 612). Adopted and modified by writer.

The following are the characteristics for both as summarized by Harlen and James (1997), they suggested the characteristics of formative assessment as follows:

a) It is essentially to promote learning

b) Monitoring each students' progresses

c) Providing diagnostic information for those students who have different skills and behavior

d) Requiring students to have a central part in it, and providing good communication between teachers and students

In contrast, the characteristics of summative assessment are: a) It undertakes because the achievements of students have to be reported

b) Its progress in learning against public criteria

c) The result of different students may be combined for various purposes because they are based on the same criteria

d) Required high stakes of validity

e) Involved some quality assurances procedures (In Indonesia, the quality assurance can be by facilitating external examiners during examination)

(Harlen \& James, 1997, pp. 372-

373).

Pertaining to above distinction, for some EFL teachers, they might have in mind some 
questions to be answered like, which one is the best process for our assessment? Should we take care one approach and care-less to another? What do research suggest for both concepts? To answer such of those questions, and make it to be clear, we cannot actually ignore one concept for the sake of other, and we also need to be closed on literature of the researches. Thus, the following session will discuss what do literatures pointing about regarding its practice.

\section{b. Interaction between Formative and Summative Assessment}

Studies following the superiority between those types of assessments receive little attention until Black and William reviewing two critical articles written by Crooks, 1988 and Natriello, 1987, then highlighting over 160 journals from several countries during a nineyear period, they finally concluded that formative assessment is "clearly a means to improve students' achievement" (Sardareh \& Saad, 2012, p. 344).

Same study by Black and William's (1998) in Brown and Abeywickrama (2010) revealed that, "over 540 research studies found that formative assessment was superior to summative assessment in providing crucial information to classroom teachers" (p. 8). Later, a study by Sardareh and Saad in Malaysian educational context also proved that formative assessment towards social cultural perspective of education improve students' learning when it is leaded by formative feedback (Sardareh \& Saad, 2012).
To maintain precisely between formative and summative based on above portrayals, we cannot argue that formative is totally superior than summative, because they actually have their own processes and objectives. If the assessment seeks to provide learning progress and creative thinking by student, then formative is considered as the best choice to be employed. But, when schools want to measure it accountability whether the goal has been achieved or not, then summative would be the answer. Likewise, "to be or not be formative/summative is a matter of degree, of intensity, and not of pure form, therefore, it is inaccurate to state that a certain form of assessment is formative or summative per se" (Marsch, 2007; Kennedy et al., 2008, as cited in Ghiatau, Diac, \& Curelaru, 2011, p. 221).

So, frequently testing students at the end of each unit (summative) might be helpful but it does not take into account the importance of formative thinking. Instead, "teachers should use different assessment methods (formative) other than paperpencil tests, to provide continuous evidence of students' progress in mastering knowledge and skills required to achieve learning goals" (Sardareh \& Saad, 2013, p. 2494).

The benefits of formative over summative has also cleared studied by Black and William (1998), they explored when teachers strengthened formative in the classroom, it will offer lot of advantages for students, especially for students who have not performed well (Meyer, 2009). Thus, for EFL teachers -although we cannot totally agree that they are powerless for summative-practicing formative 
will benefit the learning outcomes for summative purposes. To be formative, there are certain strategies that can be used in the class, at least include following:

a) Criteria and goal setting; students need to understand the learning target and criteria to reach it.

b) Observation; walking around through the class to identify the evidence of students' understanding about the topic, they perhaps need clarification on something, use recording or another media if possible to giving next feedback.

c) Questioning; Addressing good questions to investigate the deeper understanding of students. It is better to provide discussion oriented among students in order to decrease mistake-phobia.

d) Self and peer assessment; students help each other to review friends' tasks and understanding

e) Student record keeping; students monitor their own progress and record the improvement.

(Garrison \& Ehringhaus, 2007).

Contemporary studies in so many literatures clinched the awareness that the concept of formative assessment still becomes an interesting topic to be discussed, it does not mean and not necessarily to split away a formative from a summative, but formative arguing is more interesting then summative because it has deeper knowledge on the interaction between students and teachers. Somehow, a successful formative feedback involving teachers and students will promote better summative outcomes.
As EFL teacher, teaching English during school day cannot be separated by using some techniques and media. However, whatever the techniques applied massively by them, they also cannot ignore the assessment procedures to measure students' performances. If they are solely dependable by summative process, the EFL teachers would not outstandingly used the result for giving feedback to students.

The best way to be considered is using formative way to continuously evaluate students' performances, they may find some students who have in mind the difficulties in certain topics, or students who are very slow in reading or speaking. Such of this situation, a formative teacher could evaluate students by free-paper test, he or she may be consolidating the learning problems face by students to provide more suitable measurement, or teacher can get help by another student to ask some questions or peerreview. The result then used for determining next teaching strategies to improve teaching and learning in the classroom. In this step, using result to improve teaching and designing next proper media for learning considered as formative ways. EFL teachers who are successfully and continuously adapting this procedure will get better English performances by students instead just measuring students' progress at the end of semester.

\section{CONCLUSIONS}

To sum up our final discussion, we may literally be borrowing the explanation by Scriven, 
that we use the terms "formative and summative evaluation to differentiate between the two roles evaluation may play in education. Using evaluation in the development or improvement of some educational process is formative. Using evaluation in decision-making about the end result of an educational process is summative" (Scriven, 1967, pp.40-43, as cited in Brookhart, 2001, p. 153). Dispute summative can someway use feedback for formative purpose, it seems the roles of the teachers would take so little function for students' improvement. It is then suggested for EFL teachers, they should immense formative procedures over summative to enhance the learning target which has been previously shared with students. Eventually, if it is successfully offered and applied massively by teachers, the earlier problems found such as cheating, lower students' grade, would be diminished, and positively change the learning behavior. In addition, will not possible to transform teachers' conception and practice from being an "assessment of learning" into assessment for learning".

\section{REFERENCES}

Brookhart, M, Susan. (2001). Successful students' formative and summative uses of assessment information. Assessment in Education: Principles, Policy \& Practice, 8(2), pp. 153-169. doi: 10.1080/09695940123775

Brown, H. D. (2004). Language assessment: Principle and classroom practices. White Plains, NY: Longman

Brown, H. D., Abeywickrama, P. (2010). Language assessment: Principle and classroom practices. NY: Pearson Longman

Garrison, C., \& Ehringhaus, M. (2007). Formative and summative assessments in the classroom. Association for Middle Level Education. Retrieved from http://www.amle.org/Publicatio ns/WebExclusive/Assessment/t abid/1120/Default.aspx

Ghiatau, R., Diac, G., \& Curelaru, V. (2011). Interaction between summative and formative in higher education assessment: Students' perception. Procedia Social and Behavioral Sciences, 11 , pp. 220-224

Gulikers, J. T. M., Biemans, H. J. A, Wesselink, R., and Van der Wei, M. (2013). Aligning formative and summative assessment: A collaborative action research challenging teacher conceptions. Studies in Educational Evaluation, 39, pp. 116-124

Harlen, W., \& James, M. (1997). Assessment and learning: Differences and relationships between formative and summative assessment. Assessment in Education: Principles, Policy \& Practice, 4(3), pp. 365-379 
Hughes, A. (1989). Testing for language teachers. NY: Cambridge University Press

Lam, R. (2013). Formative use of summative tests: using test preparation to promote performance and selfregulation. Asia-Pacific Edu Res, 22, pp. 69-78. doi: 10.1007/s40299-012-0026-0

Marshall, B. (2011) Testing English: Formative and summative approaches to English assessment. London: Continuum International Publishing Group.

Meyer, H, Wilhelm. (2009). When you just get a mark and a nasty comment, what's that called? Summative assessment: Creating an enabling environment for formative assessment. Southern African Linguistics and Applied Language Studies, 27(2), pp. 215-228

Misanchuk, E. R. (1978). Descriptors of evaluations in instructional development: beyond the formativesummative distinction. Journal of Instructional Development, 2(1), pp. 15-19

Northern Illinois University, Faculty Development and Instructional Design Center. (n. d). Formative and Summative Assessment. Retrieved from Retrieved July 22, 2015, from

https://www.azwestern.edu/lear ning_services/instruction/assess ment/resources/downloads/form ative

and_summative_assessment.pdf

Sardareh, S.A., Saad, R, M. (2012). A sociocultural perspective on assessment for learning: The case of a Malaysian primary school ESL context, ProcediaSocial and Behavioral Sciences, 66, pp. 343-353

Sardareh, S. A., Saad, R, M. (2013). Defining assessment for learning: A proposed definition from a sociocultural perspective, Life Science Journal, 10(2), pp. 2493- 2497

Sardareh, S. A., Saad, R, M. (2013). Malaysian primary school ESL teachers' questions during assessment for learning, English Language Teaching, 6(8), pp. 19. doi: 10.5539/elt.v6n8p1

Taras, M. (2005). Assessment: summative and formative Some theoretical reflections. British Journal of educational Studies, 53(4), pp. 466-478. University of Sunderland, Blackwell Publishing Ltd

Taras, M. (2009). Summative assessment: the missing link for formative assessment. Journal of Further and Higher Education, 33(1), pp. 57-69. doi:

10.1080/03098770802638671

Wei Wei. (2015). Using summative and formative assessments to evaluate EFL teachers' teaching performance. Assessment \& Evaluation in Higher Education, 40(4), pp. 611-623. doi: 
$10.1080 / 02602938.2014 .93960$

9

Wholey, J. S. (1996). Formative and summative evaluation: Related issues in performance measurement. Evaluation

Practice, 17(2), pp. 145-149 